\title{
New perennial grains in African smallholder agriculture from a farming systems perspective. A review
}

\author{
Ellinor Isgren ${ }^{1}\left(\right.$ D $\cdot$ Elina Andersson ${ }^{1} \cdot$ Wim Carton $^{1}$
}

Accepted: 20 January 2020 / Published online: 18 February 2020

(C) The Author(s) 2020

\begin{abstract}
Perennial grain crops are gaining increased attention from researchers as one possible solution to agriculture's many sustainability challenges. In the Sub-Saharan African context, perennial varieties of crops such as sorghum, rice, and pigeon pea have potential to provide numerous benefits for smallholder farmers. The introduction and adoption of new crops and practices is however a complex process that needs to be approached from an interdisciplinary and participatory perspective. We here review the small but growing body of knowledge about on-farm adoption and the use of perennial grains around the world, as well as the more extensive literature of farming systems research. We conclude that a farming systems approach offers a fruitful entry point for informing the emerging research agenda around perennial grains in African smallholder agriculture. Yet, a comprehensive understanding of the potentials and challenges of perennial grains also requires cross-scalar analysis capable of looking beyond the farming system. We thus outline five key considerations for developing and studying new perennial grains in smallholder contexts, i.e., (1) smallholder farming systems are complex, diverse, and locally adapted; (2) decision-making is shaped by various resource constraints; (3) farming is often "semisubsistence" and forms part of broader livelihood strategies, wherein risk is an important factor; (4) gender relations and roles influence many aspects of smallholder farming systems; and (5) analyses of farmers' production systems, decision-making, and livelihood strategies must be embedded within a broader political-economic context. Based on these considerations, we suggest directions and examples of key questions for future research and derive methodological implications for how such research could be approached.
\end{abstract}

Keywords Perennial crops $\cdot$ Farming systems $\cdot$ Smallholders $\cdot$ Technology adoption $\cdot$ Sub-Saharan Africa $\cdot$ Sorghum $\cdot$ Pigeon pea $\cdot$ Rice $\cdot$ Sustainability

\section{Contents}

1. Introduction

2. Methodology

3. On-farm adoption and experiences of perennial grains: Preliminary insights from around the world

4. Perennial grains and African smallholder agriculture: Drawing lessons from farming systems research

4.1 What characterizes smallholder farming systems, and what are the implications for perennial grains?

4.1.1 Smallholder farming systems are complex, diverse, and locally adapted

Ellinor Isgren

ellinor.isgren@lucsus.lu.se

Lund University Centre for Sustainability Studies, Lund, Sweden
4.1.2 Smallholders' resource endowments are highly diverse, including at the local and intrahousehold level

4.1.3 Farming is often "semi-subsistence,", and frequently forms part of broader livelihood strategies wherein risk is an important decisionmaking variable

4.1.4 Gender relations and roles influence many aspects of smallholder farming systems.

4.2 Beyond the farming system: the need for multiscale analysis and critical perspectives

5. Synthesis: implications for perennial crop research

6. Conclusions

References

\section{Introduction}

A transition to perennial agriculture has been proposed as a viable pathway towards sustainable food production systems 
(Jackson 2002; Cox et al. 2006). Compared with annual crops, deep-rooted perennials improve soil structure and contribute to soil and water conservation, decrease vulnerability to drought, and dramatically reduce the need for tilling, weeding, and use of external inputs. Because this simultaneously contributes to climate adaptation and mitigation, and enhances biodiversity and ecosystem functions across farming landscapes, perennial crops and cropping systems could help address some of agriculture's most pressing challenges (Crews et al. 2018). Particularly since the 1980s, significant efforts have gone into the development of new crops that could help achieve this vision. In recent years, rapid progress has been made in the development of perennial alternatives to important staple crops such as wheat and rice (Cox 2014).

The benefits of this bold agricultural vision could be particularly significant for developing countries. Scholars have highlighted the potential of perennial grains to help achieve "sustainable intensification" of smallholder agriculture in Sub-Saharan Africa (SSA); that is, "increasing crop production per unit area and enhancing environmental, economic, and social sustainability" (Reganold 2013:256). Peter et al. (2017:283) for example, argue that perennial grains "offer smallholder farmers of marginal lands a sustainable solution for enhancing resilience and minimizing risk in confronting global change, while mitigating social and edaphic drivers of low and variable production." A recent review of perennial grains in the African context therefore urges agronomists to "broaden their view beyond an annual-centric one, and consider investing in the perennial grain pipedream" (Snapp et al. 2018). Glover et al. (2012) meanwhile see investments in the research-and-development of perennial grains as an integral part of a much broader push towards the "perenniation" of African cropping systems, including more investments in agroforestry. This effort is still in its infancy; so far, research on perennial grains for smallholder contexts has primarily focused on improving crop yield and quality through plant breeding, and proposed crops such as perennial sorghum (Sorghum bicolor $\times$ Sorghum halepense) and rice (Oryza sativa $\times$ Oryza longistaminata) (Fig. 1) remain experimental or maladapted to various African conditions.

Realizing the promises of perennial grains will require more than just investments in crop improvement. New crops and cropping systems must be developed with regard for farmers' motivations to adopt perennials, their potential uses, and the viability of perennial cropping systems under various socio-economic and agro-ecological conditions. Diffusion furthermore depends on a range of broader social, economic, and political factors. Given the challenges and stakes associated with promoting new agricultural practices and technologies, especially under conditions of extreme poverty, we argue that it is important for researchers (whether agronomists or others) who take up this challenge to do so with these complexities in mind. This must occur early on, so as to avoid the well-known problems of traditional "technology transfer" models of agricultural development, in which farmers' systemic perspectives and contextual factors are considered much too late (Chambers and Jiggins 1987). This is particularly important as perennial grains can be considered an example of a "transformative technology," i.e., an innovation that fundamentally differs from conventional agriculture in its "architecture, functionality, component principles and underlying science" (Adebiyi et al. 2016:102).

For several decades, questions surrounding uptake, use, and impacts of new technology in smallholder agriculture have been fruitfully studied through the lens of "farming systems," under rubrics such as "farming systems research." The purpose of this article is to draw key insights from this research area to inform the emerging research agenda around perennial grains in Sub-Saharan African smallholder agriculture, in terms of pivotal questions and promising methodological approaches. This leads us to highlight the importance of participatory design, monitoring, and evaluation of on-farm trials, detailed empirical investigations of the compatibility of such crops with smallholders' existing agricultural systems, farming practices, and overall livelihood strategies. Attention to (often gendered) heterogeneity in regard to access to, and control over, various assets is critical in this. Finally, we consider complementary perspectives which a farming systems approach is prone to neglect-most importantly, broader political-economic forces that shape agricultural change all the way down to the farm level. Our focus lies on grain crops which are currently grown as annuals but for which perennial counterparts are being developed - or in some cases (like pigeon pea (Cajanus cajan) Fig. 1), existing perennial crops that are most often grown as annuals. While this focus excludes established perennials like tree crops, one could reasonably expect these insights to be relevant to perenniation efforts more generally.

\section{Methodology}

This article builds on a literature review conducted in two stages. First, we systematically reviewed literature on perennial grain agriculture to assess the current state of knowledge about factors and conditions affecting adoption of new perennial grain crops around the world. Using Web of Science, we conducted a broad initial search ("perennial agriculture" OR "perennial crops" OR "perennial grain*" OR "perennial rice" OR "perennial sorghum" OR "perennial wheat" OR "perennial pigeon pea" OR "perennial cropping system*") which was narrowed down using more specific search terms in accordance with the focus of this study ("adoption" OR "uptake" OR "economic" OR "socio-economic" OR "politic*" OR "smallholder*" OR "farming systems" OR "Africa"). Review of 307 abstracts resulted in 67 articles being reviewed 
Fig. 1 Research on perennial grains in the African context is still in its infancy but studies and experiments have been conducted in several countries; here, in Uganda. Top pictures: experimental perennial rice fields. Bottom left: pigeon pea seeds. Bottom right: experimental perennial sorghum seed head. Photos adapted from Wim Carton
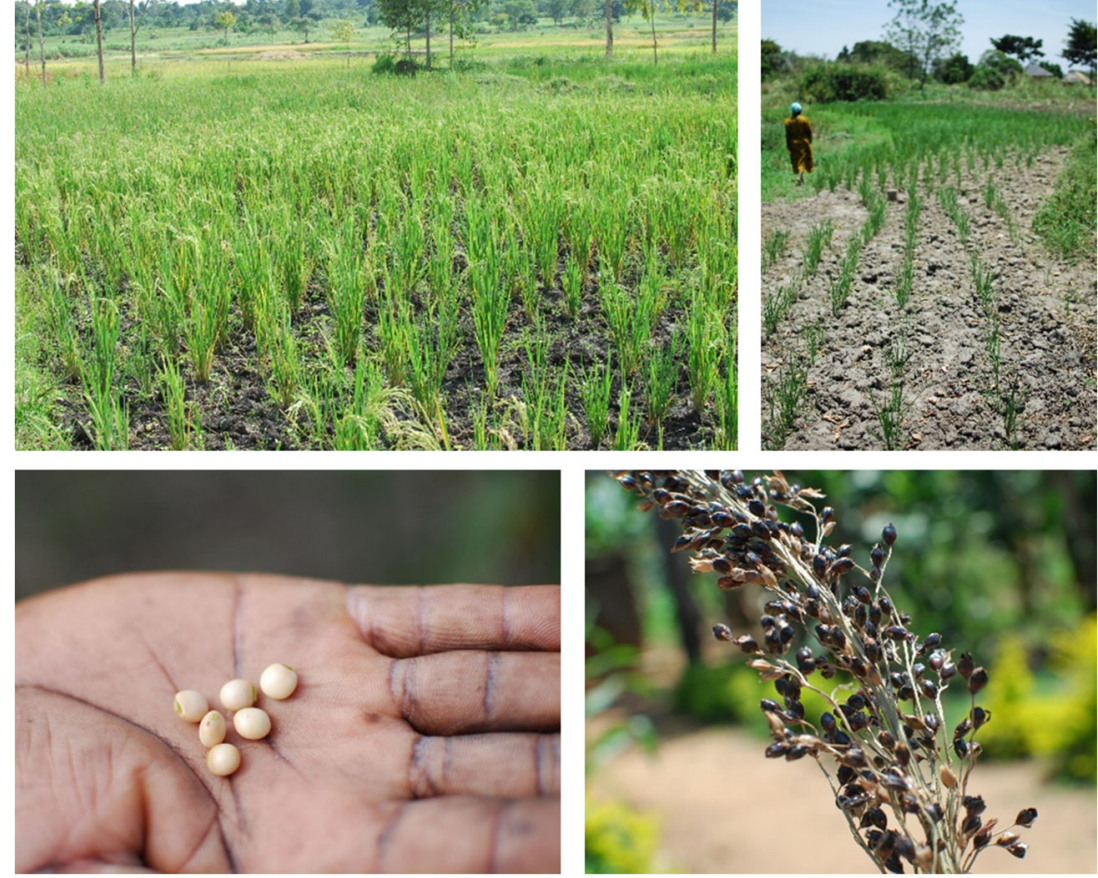

in full, with 11 articles (excluded from Web of Science) added via citations.

In the second stage, we conducted a focused review of the farming systems literature, seeking to identify major factors affecting uptake of new crops and practices in African smallholder farming systems and derive likely implications for research on perennial grains. We did not aim for a comprehensive review of this large body of literature, but instead started from recent reviews framed around goals like "sustainable intensification", and then used a snowball approach until we reached a point of saturation, i.e., when no new significant information, themes, concepts, or references on the topic emerged (Saunders et al. 2018). While engaging with this literature, we also paid attention to recurring critiques of the farming systems approach. Insights from these can help research around perennial grains to avoid known pitfalls as it moves forward.

\section{On-farm adoption and experiences of perennial grains: preliminary insights from around the world}

The rationale for a transition towards perennial grains has at this point been thoroughly documented and discussed, and will not be extensively covered here. Above all, perennial grains are being developed as a way to mitigate (or even reverse) the negative environmental impacts of agriculture; problems such as soil erosion, nutrient leaching, eutrophication, salinization, water logging, and high energy intensity are often named (Bell et al. 2008; Finlayson et al. 2010; John et al. 2017; Zhang et al. 2017; Crews et al. 2016). Many of the ecological benefits of perennials can be attributed to their extensive root systems which, together with greatly reduced soil disturbance, help build up soil organic matter, stabilize soils, and improve nutrient uptake (Crews and Rumsey 2017; Larkin et al. 2014). This could also reduce agriculture's contribution to greenhouse gas emissions, even to the point of considerable net carbon sequestration, through building up soil carbon and reducing the need for fertilizers (Kell 2012; de Oliveira et al. 2018; Crews et al. 2018). Their ability to draw water from deep soil layers in turn makes perennial crops less vulnerable to water stress (de Oliveira et al. 2018), a particularly attractive feature in regions with recurrent droughts and limited access to irrigation.

These many benefits notwithstanding, there remain important obstacles to the uptake and use of perennial grains. Most significant among these is that perennial grains currently produce lower yields than their annual counterparts, mainly due to a lower harvest index (Martens et al. 2015). Yet important strides forward have been made in recent years, particularly for perennial rice (Zhang et al. 2014) and intermediate wheatgrass (Thinopyrum intermedium), commonly known as Kernza ${ }^{\circledR}$ (Ryan et al. 2018). In a study conducted in China, Huang et al. (2018) compare the agronomic and socio-economic performance of a perennial rice variety to commonly used annual varieties, in part through farmerparticipatory experiments. They find that the perennial variety produces comparable grain yields, while having lower costs and acceptable milling and cooking quality. 
Farmers particularly valued the reduction in labor and labor intensity - not least for women and children, who are often responsible for transplanting. For Kernza ${ }^{\circledR}$, yield improvements have not advanced as far as for perennial rice, and our knowledge about farmer uptake and use so far builds on hypothetical scenarios rather than actual experiences. Here too however, research suggests that simplistic measures of yield should not be treated as the only (or necessarily most important) factor of importance to farmers. Glenna et al. (2011) tested attitudes among wheat farmers in the US northwest and found interest to be highest with those who demonstrate a general interest in environmental conservation, who have considered transitioning to organic farming and who express skepticism about the growing role of private actors in agricultural research. Given the diversity of factors that shape farmers' selection of crop varieties, the authors caution that "end users may have an interest in a technology for reasons other than what the technology's developers intended" (Glenna et al. 2011:221). Diverse priorities are also noted by Adebiyi et al. (2016), who through interviews with farmers in the US midwest highlight the appeal of planting perennial wheat on underused or marginal land. In such cases, lower yields constitute less of a barrier, though adoption is likely to occur on a limited scale. The argument that perennials enable more productive use of land not suitable for annual crops, or can help restore land prior to its return to annual cropping, is made by several other scholars with specific reference to the US context (Glover et al. 2010; Ryan et al. 2018). In an interview-based study from Sweden, Marquardt et al. (2016) meanwhile note that the importance of yields may be lessened by the existence of substantial agricultural subsidies and by benefits like labor saving, time flexibility, and lower expenses for fertilizers and fossil fuels.

A second aspect highlighted in several studies is that while yields of individual crops certainly matter to farmers, introduction of crops can also interact with other crops and farming system components. For example, many perennial grains show high compatibility with legume intercropping. This has potential to produce benefits in terms of soil fertility and pest management, but may also raise management challenges. Harvesting is one example, and issues such as synchronized grain maturation, mechanical harvesting, and seed separation in perennial polycultures must be further studied (Ryan et al. 2018). Similarly, there are both opportunities and challenges related to perennial grains in integrated crop-livestock production. In Australia, Newell and Hayes (2017) argue that perennial wheatgrass can constitute an attractive dual-purpose, but aside from yields it is also important to understand qualities like nutrient balance of the resulting feed. Zhang et al. (2017) make a similar argument in the Chinese context, noting that producing livestock feed and forage is often an important function of smallholder cropping systems, and that further enquiry is needed into how perennial rice varieties fit into such systems.

Finally, a few studies indicate that challenges to use of perennial grains are not only located at the level of the individual farmer and his/her production system. Glenna et al. (2011:214) highlight that social structures "place limits on the types of agricultural technologies available and the capacities of farmers to utilize them; consequently, limiting the agency of farmers." This notably includes plant breeding, which is sometimes seen as an unbiased, universally beneficial endeavor that is free of political and economic interests even though this is clearly not the case (Glenna et al. 2011). Also pointing to structural constraints, Crews and Rumsey (2017) argue that progress in upscaling perennial polycultures in the USA is likely to be limited by circumstances such as government subsidies, which currently incentivize the production of a few annual crops, high levels of market consolidation (e.g., seeds, agrochemicals, grain trade) and the "global governance and economic structures" within which food systems are embedded. Jordan et al. 2016 too place the responsibility for action with a wide array of actors, including policy makers. To ensure the "sustainable commercialization" of perennial grains, they argue, will require a "coordinated innovation process that integrates a new crop into the agriculture of a region, while intentionally addressing economic, environmental and social sustainability challenges via multi-stakeholder governance." (Jordan et al. (2016):1).

This emerging literature raises important points that can help inform a discussion on the adoption of perennial crops in a variety of agricultural settings. At the same time, there are limits to drawing lessons from relatively resource-intensive agriculture for adoption in the more resource-constrained contexts of smallholders in SSA. More generally, one can question the transferability of both knowledge, management techniques and germplasm across geographical, environmental, agronomical, and cultural settings. Not only does "investing in the perennial grain pipedream" for Africa require breeding for tropical settings and the local adaptation of germplasm that has often been developed under very different temperate conditions (Cox et al. 2018), it also mandates that researchers engage with local specificities as both opportunities and potential barriers to implementing a perennial agricultural vision. In the remainder of this article, we draw on a farming systems perspective to outline some of the ways in which this can best be accomplished, focusing on those aspects that warrant particular consideration in African smallholder contexts. As we do so, we incorporate the relatively few but important empirical insights from existing studies on perennial grain agriculture in SubSaharan Africa. 


\section{Perennial grains and African smallholder agriculture: drawing lessons from farming systems research}

In the 1960s, the technological packages that were widely recommended to farmers in Africa, Asia, and Latin America began to receive more critical attention from agricultural economists, who often found these recommendations to be poorly designed (Norman 2002). Common insights were that (a) contrary to dominant expectations about farmers being inherently conservative and change-averse, farmers tend to be "natural experimenters"; (b) farmers' production environments are highly heterogeneous, thus technologies must be easily adapted to context-specific needs; (c) even when technologies are well adapted to local biophysical conditions, adoption is often hindered by incompatibility with farmers' socioeconomic realities. Many economists concluded that the neoclassical paradigm underpinning common recommendations was too static to account for the complexities and uncertainties that characterize smallholder farming, and that the reductionist, expert-driven methods used in agricultural research are needed to make way for more active participation by farmers (Norman 2002). This became the beginning of an approach termed "farming systems research," which rapidly gained traction. Over the next few decades, the approach evolved theoretically and methodologically, incorporating aspects such as gender, sustainability, and new participatory methods. As an approach to agricultural research, the farming systems approach can be thought of as "a basket of methods for researchers to elicit a better understanding of farm households, family decisions and decision-making processes" (Collinson 2000) rather than as a particular method. It is founded on a "conceptualisation of farming as a bounded system in which multifaceted and historically-embedded component partssocial, political, ecological, climatic, cultural, and economic processes-interact in dynamic ways" (Whitfield et al. 2015:55). It is this extensive and inclusive understanding of farming and farming systems that makes this literature interesting from a technology adoption and adaptation point of view.

\subsection{What characterizes smallholder farming systems, and what are the implications for perennial grains?}

Albeit a heterogeneous category, smallholder farming systems are widely known to be complex, diverse, and risk-prone (Chambers et al. 1994). Smallholders face many social and environmental stressors, including persistent poverty, high disease burdens, land pressure, and climate variability and change, implying that smallholder systems are subject to continuous adjustment to changing circumstances (Morton 2007; Jerneck and Olsson 2013). This, in turn, means that introducing new crops and technologies often has unpredictable, and highly contextual, outcomes. Below, we present in greater detail the most important characteristic features of smallholder farming systems that have been found to shape uptake of new crops, technologies, and practices, and therefore ought to be considered in perennial grain development and promotion.

\subsubsection{Smallholder farming systems are complex, diverse, and locally adapted}

Diversification (in both space and time) functions as a way to spread risk and strengthen farming systems resilience in the face of uncertainty and variability — both biophysical and economic (Waldman and Richardson 2018). The necessity for smallholders to adapt their farming systems to local agroecological conditions creates further heterogeneity, making it problematic to speak of "African smallholder farming systems" in too general terms. It is important to understand how perennial grains fit into the various complex agroecosystems that exist throughout Sub-Saharan Africa, where they will be interacting with several other agroecosystem components. One example is how perennial grains might be integrated with maize (Fig. 2), since maize is an important staple crop in many parts of SSA, but one that is often associated with high rates of soil degradation. According to Peter et al. (2017:288), the "integration of perennial pigeon pea or sorghum into maizebased farming systems shows wide spatial applicability across Africa," a conclusion they reach through remote sensing data of temperature and precipitation. While this gives a broad indication of applicability, local conditions can vary significantly, and applicability in actuality will depend on a wide range of variables, thus calling for more grounded assessments. Another aspect that indicates potential applicability is that perennial grains often work well when intercropped with legumes (Ryan et al. 2018). In many parts of Africa, legumes have traditionally formed part of smallholder farming systems and have widely recognized ecological, economic, and social benefits. That being said, it has been observed that despite the

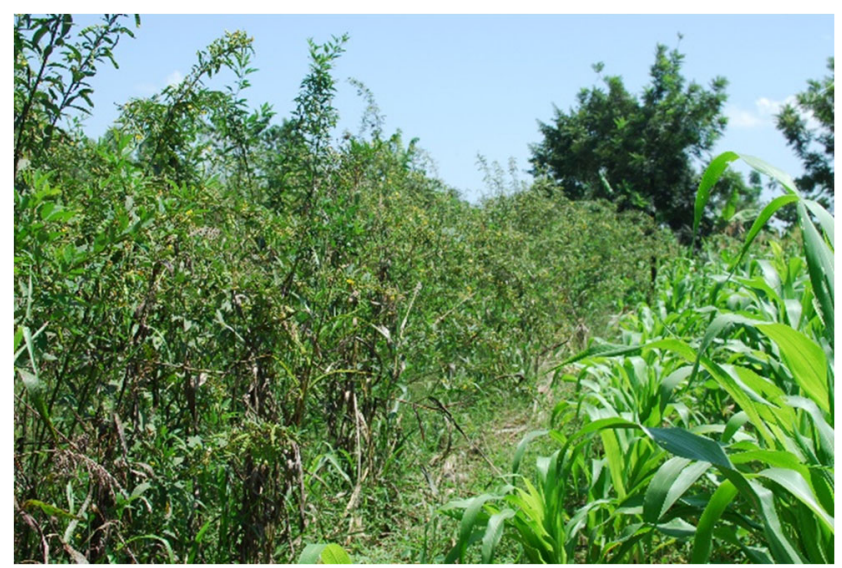

Fig. 2 Pigeon pea grown alongside maize in Uganda. Photo adapted from Wim Carton 
obvious potential of legume intercropping, adoption by smallholders in many parts of the continent has remained poor (Ojiem et al. 2006). Researchers seeking to develop and study perennial grains should take note of the lessons; this holds for legume intercropping specifically, and for technology uptake in general "great potential" does not mean that adoption is self-evident. Wide-ranging reasons, including those seemingly unrelated to the question at hand, might lie behind a reluctance or refusal to adopt a new crop.

For example, diversity over time (that is, crop rotation) has traditionally been a common feature of smallholder farming for purposes of soil conservation and pest management, although it can be constrained by factors like land shortage and fragmentation (Sibanda et al. 2000) and lack of markets (Umar et al. 2011). Researchers must take any concerns seriously that farmers may have about perennial crops further inhibiting crop rotation and ensure ways in which its agroecological functions can be maintained (or rendered unnecessary) in perennial cropping systems.

Crop-livestock interactions constitute another crucial issue to consider in smallholder systems, as indicated in section 3; small ruminants, together with chickens, pigs, and cattle, "form an important economic and ecological niche in small farm systems" (Devendra 2001:1483). As an integral part of smallholders' diversification strategies, livestock make important contributions to food security and income generation (Asante et al. 2018). This can pose challenges for perennial cropping systems; in a study from Mali, Rogé et al. (2017) found crop damage caused by livestock to be one of the main concerns expressed by farmers when discussing the integration of perennial grains. An interview study with maizegrowing farmers in Malawi arrived at similar findings (Rogé et al. 2016). Due to the risk of significant damage, Grabowski et al. (2019:91) assume in their choice experiments on perennial pigeon pea that farmers would only plant this crop "where livestock and wildlife would not consume it." On the other hand, Rogé et al. (2017) also point to the potential to develop perennial sorghum that can withstand grazing pressure, something that should be particularly attractive in areas where pastoralism is practiced. Furthermore, perennials tend to have a higher amount of non-grain biomass than most annuals, which can be used as livestock feed (Snapp et al. 2018). In the specific case of perennial sorghum, Nakasagga et al. (2018:152) argue that its "vigorous postharvest vegetative growth (...) can provide additional benefits in East African agriculture, where grazing potential after the end of the rainy season is often limited."

\subsubsection{Smallholders' resource endowments are highly diverse, including at the local and intra-household level}

An additional dimension of diversity that must be taken into account are the variegated household resource endowments, in terms of labor, land, and livestock, that impact the adoption of "sustainable intensification" practices (Vanlauwe et al. 2014). One common way to recognize variability among farms and across localities in farming systems research is to categorize households into typologies based on resource endowments. Tittonell et al. (2010) for example propose a typology that combines household resource endowment with another key variable, namely dependence on off-farm income (Fig. 3; see also section 4.1.3). Although there is a risk of creating overly simplified and static divisions, farm typologies may be helpful for identifying the overall strategies that households pursue in response to opportunities and constraints in their environments (Kuivanen et al. 2016). This can guide the adaptation of new crops and practices in accordance with farmers' needs and priorities (Scoones 2009; Tittonell et al. 2010). Moreover, there can be significant variation within households, not least due to gender disparities in relation to land, access to credit, wages, and so on (Sewpaul 2008). Even under significant labor and land constraints, however there is often room for smallholders to modify their farming systems in ways that generate improvements in production and sustainability. When doing so, farmers often allocate limited resources in ways that optimize performance of the whole farm, which may conflict with maximizing yields of individual crops (Dogliotti et al. 2014a). Perennial crops might create interesting opportunities here because of their lower input costs, in terms of less frequent reseeding, natural mechanisms for pest management, lower fertilizer requirements, and lower (or no) irrigation needs (Waldman and Richardson 2018; Pimentel et al. 2012). More in-depth and empirical understanding of these benefits, of how farmers perceive them in relation to potential trade-offs, and how they ultimately play

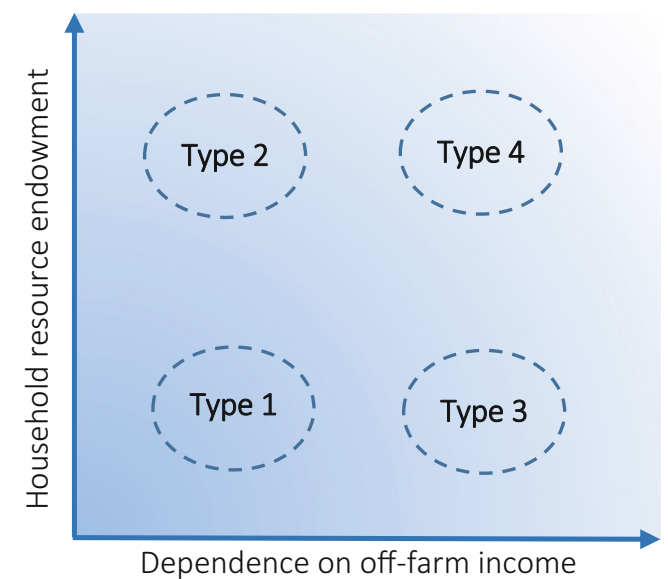

Fig. 3 Farm typology that combines household resource endowment and dependence on off-farm income (adapted from Tittonell et al. 2010). Note that the resulting types (and the number of types-here, four) depend on the specific research context. Farm typologies can help guide subsequent farming systems research (e.g., on crop development, performance, and/or adoption) 
out under diverse smallholder conditions, are important questions for future farming systems research on perennial crops.

Access to productive land is one of the more common resource constraints in many African countries, whether due to unequal land distribution, tenure insecurity or fragmentation due to population growth (Jayne et al. 2014; Holden and Otsuka 2014). Not least due to the continent's varied colonial history (e.g., Bernstein 2005), many forms of land tenure exist in Africa and multiple systems may co-exist in one location, creating a complex patchwork of land tenure relations. Tenure insecurity has been cited as an obstacle to long-term investments in land in SSA, with implications for practices such as tree-planting (Unruh 2008) but potentially also for perennial grain crops. Decreasing farm sizes may furthermore render farms too small for investments in lower-yielding and less flexible land uses, in contrast to settings where farmers may have "marginal" portions of large landholdings. That said, in a study set in a sorghum-growing region of Mali, Rogé et al. (2017) find perennial grains to be highly compatible with existing customary land tenure relations and the resourcesharing logic of existing land use.

The agricultural quality of available lands is another important variable in farmers' adoption decisions. There is considerable heterogeneity in soil fertility status and other qualities between regions, landholdings, and plots (Andersson 2014), but various forms of soil degradation such as nutrient depletion, and erosion constitute a serious challenge in many parts of SSA (Andersson et al. 2011; Henao and Baanante 2006). According to Giller et al. (2011), rehabilitation of degraded soils is a challenge for many smallholders as it requires considerable investment of time, capital, and other resources. Perennial grains have considerable potential to help address this problem; their positive impacts on soils have been widely documented, yet they are not necessarily associated with high costs or labor requirements, as shown in the case or rice (Huang et al. 2018). Peter et al. (2017) emphasize the potential of perennial grains (specifically sorghum and pigeon pea) to contribute to sustainable agricultural intensification in Africa, especially where topography and/or farming practices have resulted in erosion or depletion of soil organic matter. Where the productive capacity of land is low, qualities like soil improvement, stabilization, and water-stress tolerance may well compensate for lower maximum theoretical yields and boost production potential over time. Conversely, where agricultural production capacity is relatively high, farmers might show less interest in low-yielding and soil-improving crops and cropping systems, and therefore might require additional incentives for adoption. Empirical evidence for this is provided by Waldman et al. (2017), whose choice experiments in Malawi show a lower interest in pigeon pea-growing among farmers with high maize potentials and a higher adoption potential in areas with poor soil fertility and low maize production. Grabowski et al. (2019) similarly find that relatively dry seasons seem to demonstrate the potential for perennial pigeon pea to farmers, indicating higher adoption potential in marginal environments.

Labor constraints, costs, and returns similarly form an important decision-making factor in smallholder farming systems, especially during certain times of year (Giller et al. 2011). Leonardo et al. (2015) for example find productivity in maize-based smallholder farming systems in Mozambique to be constrained by labor rather than land, especially during times of high weeding demand. This not only highlights the importance of total labor availability, but also hints at some of the important ways in which timing matters, as both availability and cost of labor can vary significantly over the year. It is therefore not necessarily meaningful to calculate labor demands in a simple metric. Zero tillage, for example, one of the presumed benefits of perennials, saves labor at the time of planting but may require more labor for weeding, which is often a more challenging concern (Giller et al. 2011). Uneven maturation, which poses challenges in large-scale mechanized agriculture, may be viewed differently by smallholders since this implies that labor needs for harvesting get distributed over time. In their study in Mali, Rogé et al. (2017) however found that both men and women highlighted reduced labor requirements as the most important benefit when discussing the idea of growing perennial sorghum. Peter et al. (2017:288) meanwhile are referring specifically to African smallholder contexts when they argue that perennial grains should mainly be promoted in "locations where labor constraints reduce agricultural system efficiency." More empirical studies of the suggested labor-saving benefits of perennials crops are clearly necessary.

\subsubsection{Farming is often "semi-subsistence," and frequently forms part of broader livelihood strategies wherein risk is an important decision-making variable}

Smallholders agricultural practices are often highly intertwined with households' overall livelihood strategies, which involve not only agriculture but also non-farm and/or off-farm activities. A clear understanding of the functions and potential impacts of new crops and farming technologies on broader livelihood strategies, and the various barriers that may be encountered during implementation in everyday settings, is therefore necessary (Verma 2001). That said, there is strong evidence that agriculture remains the "mainstay" of rural livelihoods in SSA (Christiaensen 2017). Production may be geared towards subsistence or income-generation, or any combination of the two; a majority of smallholders in SubSaharan Africa are best considered "semi-subsistence." Some crops are distinct "cash crops" and "food crops," but many (including staple crops) can be both, depending on variation in household needs, yields, market access, and prices. Increases in food crop production may thereby yield economic benefits, 
alongside improved household food security. This is not only because surplus can be sold, but also because many smallholder farmers in fact are net food-buyers (Masters et al. 2013). These dynamics are complex; for example due to considerable seasonality in staple crop prices, something that remains poorly understood (Gilbert et al. 2017). One implication is that for farmers who are seeking income-earning opportunities, some perennial crops are likely to be more attractive than others (e.g., rice compared with sorghum) due to their different market potentials. At the same time, where smallholders produce at least partly for their own consumption, it is important to consider local consumption patterns and preferences.

The semi-subsistence character of many SSA smallholders is reflected in the wide range of production risks faced. Farmers in many parts of Africa are increasingly linked to and impacted by the global market economy and its uncertainties, making them vulnerable not only to inherently biophysical contingencies like weather extremes and pest outbreaks (which are now being aggravated by climate change) but also to economic risks such as market shocks and price volatility (Morton 2007). Particularly vulnerable are poor smallholders, who often rely exclusively on rain-fed agriculture, lack access to insurance and credit, and are heavily dependent on agriculture for their livelihoods (Harvey et al. 2014). These different kinds of risks constitute a major factor influencing smallholders' decision-making, including whether or not to adopt a new practice, crop or cropping system (Vanlauwe et al. 2014). Perennial grains could in some respects be an appealing risk-minimizing strategy-for example, in places where droughts are recurrent and perennial crops can be convincingly shown to withstand drought better than annual counterparts. Nakasagga et al. (2018) for example highlight the potential of perennial sorghum as a drought resistant crop in East African farming systems - provided that locally adapted cultivars can be developed. On the other hand, farmers may perceive perennial grains as risky if they believe that they might act as "pest and disease reservoirs" (Snapp et al. 2018), be consumed by wildlife or free-ranging livestock before harvest (Grabowski et al. 2019), or be more exposed to depredation due to the longer time they remain in the field (Waldman et al. 2017). Stochasticity in performance and social pressure to conform are other important factors affecting adoption and disadoption in risky smallholder environments (Grabowski et al. 2019). Research on traditional perennial crops like coffee (e.g., Collier 2002) furthermore shows that smallholders may be reluctant to adopt perennials if it takes long before they produce harvestable yields. Reduced flexibility to change crops in response to changing market conditions may also be perceived as a risk. Particularly those perennials that are slow-growing (e.g., pigeon pea), and do not reach optimal yields in their first crop could be perceived as "locking in" farmers to a specific crop over several seasons.

\subsubsection{Gender relations and roles influence many aspects of smallholder farming systems}

Gender is a key factor influencing the everyday practices and micro-politics of resource use, food production, and labor division within households and communities. As a deep structure in society, it contributes to a divergence of rights, roles, interests, priorities, knowledge, and strategies among men and women (Rocheleau et al. 2013). In accessing and controlling land, for example, women are often disadvantaged (Deininger et al. 2017). This can result in reluctance to invest in land use and farming practices that require a long-term perspective (World Bank 2009; Doss et al. 2015), which could have implications for interest in and adoption of perennial cropping systems. Cropping patterns, too, tend to be gendered, with subsistence crops often regarded as "women's crops" while crops for market production tend to be controlled by men. This mirrors a more general gendered division of responsibilities within rural households, which extends not just only to agricultural activities but also to the domestic sphere and community management activities (Rocheleau et al. 2013). However, it is also important to be wary of myths and generalizations surrounding gender patterns. Christiaensen (2017) for example calls into question the widespread idea that women generally "provide the bulk of labor in African agriculture," citing recent data from several countries. Doss et al. (2015) similarly argue that gender inequalities in regard to land rights and access are more variable and complex than is reflected in the literature on African agricultural development. Acknowledging the importance of gender, Rogé et al. (2017) explore differences between men and women regarding expected advantages and challenges of integrating perennial sorghum into their farming systems in Mali. Men particularly emphasized the risk of livestock damage as a challenge, while viewing labor saving as the biggest advantage. Women also drew attention to these issues, but emphasized food security benefits and a reduced need to buy seeds to a greater extent than men. They also expressed more concern about water availability in the dry season and noted other resource limitations that may affect the viability of perennial crops. Women furthermore argued that "perennial grains may increase access to land and natural resources for women," who tend to "access resources at the margins of agricultural production" and therefore are likely to benefit particularly from improved soil quality. That said, the authors are careful to point out that these dynamics are complex and location-specific, and that perennial grains should not be assumed to automatically benefit women (or any other marginalized group). In a study on perennial staple crops in Malawi, Rogé et al. 
(2016) further caution that "an emphasis on developing cash crops often accentuates gender inequality," a dynamic that must be considered in future research and extension around perennial crops.

\subsection{Beyond the farming system: the need for multi-scale analysis and critical perspectives}

The farming systems approach has proven valuable in demonstrating that farmers' decision-making and technology adoption, as well as impacts of adoption, are complex, context-specific, and dynamic. The long history of research in this field clearly demonstrates that farmers often do not just adopt technologies "as they are" but tend to modify and combine them in ways that are suitable to their own conditions. However, farming systems research has also received criticism for the "narrowness of conceptual frameworks pinned together by practitioners preoccupied by technology adoption" (Collinson and Lightfoot 2000:2), neglecting issues such as population dynamics, sustainability, and wider macro and policy linkages. Its failure to consider the broader political, economic, and institutional environment within which smallholders operate, including aspects like government policies, rural service provision, market relations, and access to financing and information (see Fig. 4), appears to be a particularly persistent weakness (Tittonell et al. 2010; Verma 2001).

These are not new concerns. Gilbert et al. (1980:ix) cautioned early on that farming systems research "could lose its credibility if micro research is not supplemented by macro research on the political, economic, and institutional constraints on small farmers in the Third World." Similarly, Brouwer and Jansen (1989) appreciated the turn towards holism and interdisciplinarity, but urged strongly for a more critical approach which could give due attention to political economic relations and power structures as manifested both materially and ideologically. In a more recent reflection on the usefulness of farming systems research for agricultural development in Eastern and Southern Africa, Whitfield et al. (2015) acknowledge that the approach has an important role to play. But, they also argue that research must "capture the multi-level system dynamics that link on-farm decision making to broader political, social, and environmental changes" (Whitfield et al. 2015, p. 54) such as market relations, land tenure regimes, and investments in agricultural research and extension.

We suggest that interrogation of these multi-level dynamics requires research that moves beyond the farming systems approach to seek insights from other academic traditions, such as political economic analyses of agricultural policies (Swinnen 2010), seed and biotechnology (Kloppenburg 2005; Schimmelpfennig et al. 2004), and agricultural research (Sumberg and Thompson 2012). Some of the political ecology literature meanwhile could provide fruitful inspiration for more explicit attention to the justice dimensions embedded in a push for perennial agriculture, how these play out a different scales, and what constellations of "winners" and "losers" emerge from this (Robbins 2011; Gezon and Paulson 2004).

The small body of literature on perennial grains in Africa already contains strong indications that a move beyond the farming systems perspective is necessary. Snapp et al. (2018:8) for example note how they have encountered highranking agricultural officers who "equate sole crops of hybrid, fertilized maize with developed agriculture and mixed cropping systems and ratoons as legacies of the past." Their examples show that in different African countries, agricultural
Fig. 4 The farming systems perspective offers fruitful insights and useful theoretical and methodological guidance for understanding processes within (and interactions between) the local community, the household, and the farm itself. However, broader political-economic processes and structures also influence farmers' decisionmaking and their outcomes. These, we argue, require farming systems research to be complemented with other theoretical and methodological approaches, such as those commonly found within political ecology scholarship

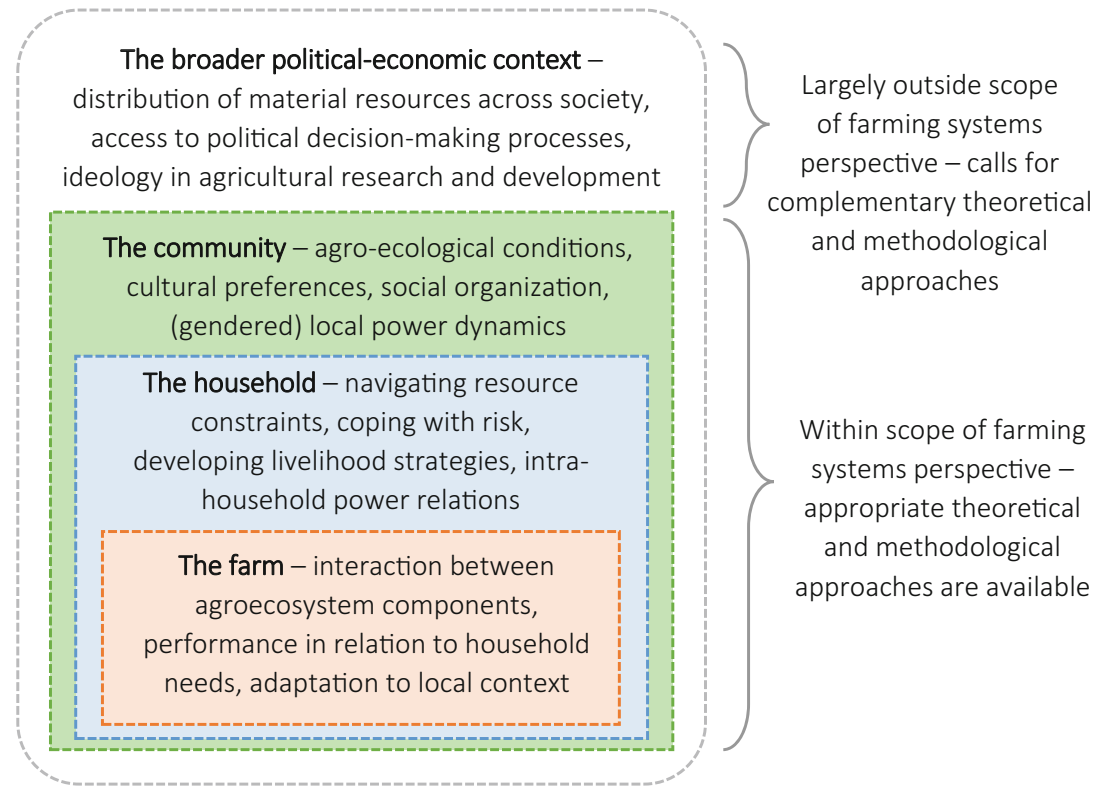


policies incentivize monocropping of commodities, typically annual grain crops with a high harvest index. It is difficult, they argue, to distinguish how much of this is driven by an "annual centric world-view," how much is influenced by other perceptions of what constitutes "modern" agriculture, and how much of it is attributable to material interests. A political ecology perspective would conceivably highlight this as one example of how the political, cultural, and economic dimensions of specific environmental management regimes intertwine and reinforce each other, into the formation of a hegemonic "assemblage" (e.g., Li 2007) of annual grain agriculture. It can also be used to turn a critical eye towards research (including plant breeding) itself. Kane et al. (2016) for example note how certain perennial crops like sorghum and pigeon pea have drawn less research interest than others, likely due to lower commercial potential. Rogé et al. (2016) provide another interesting reason to move beyond a traditional farming system focus. They briefly describe how in Malawi, colonial administrators actively discouraged indigenous practices such as intercropping and the cultivation of crops like pigeon pea and perennial sorghum, in favor of the production of maize in monocultures, with consequences for food insecurity and land degradation to this day. This illustrates the importance of applying a historical lens to work on perennial grains, because engrained colonial legacies and cultural sensitivities might very well constitute barriers to adoption in the present. Exactly what the long-term consequences of these various factors are for the development and uptake of perennial crops in smallholder contexts is, as also Snapp et al. (2018) imply, an important area of further research. It seems clear that closer attention to wide-ranging social, political, economic, and cultural dynamics will need to be an important part of this enquiry.

\section{Synthesis: implications for perennial crop research}

In Table 1, we summarize the five major points presented above and provide examples of future research questions which follow logically from an analysis of new perennial grains through a farming systems lens, complemented with cross-scalar analysis capable of capturing political-economic dynamics beyond the farming system. First, the complex, diverse, and locally adapted character of smallholder farming systems demands attention to how new crops interact with existing farming systems components and processes in a context-specific manner. This is a crucial step towards a nuanced and comprehensive understanding of the potential and challenges that perennial grains hold in different settings. Second, critical attention to social differentiation among smallholders leads to questions about who, within the heterogeneous "smallholder" category, can adopt and benefit from new crops, and what support different groups require to facilitate adoption. Third, an understanding of smallholder farming as "semi-subsistence" and farmers' decisions on technology adoption as inseparable from broader livelihood strategies invites questions about the importance of different perennial crops vis-à-vis other economic activities. Particularly pertinent in this context is the possibility that new crops help reduce risks or introduce new ones. Fourth, the centrality of gender relations in smallholder farming systems implies that men and women may view and be impacted by new crops differently. Vice versa, researchers also need to ask how the changes in farming systems might impact gender relations within households and communities. Fifth - and here is where we partly step outside the boundaries of farming systems research - we argue that it is crucial to ask questions about the broader political economic forces which shape the development and dissemination of new technologies including new crops. This involves close attention to agricultural policies and institutional support mechanisms, and also to incumbent seed provision structures and agricultural knowledge providers as possible enablers of and/or barriers to change.

Although we present these as five discrete sets of issues, it is clear from our review that in reality, they overlap and can be fruitfully combined in various ways in research projects and questions. That is, although particular characteristics may be chosen as the analytical focus, they should not be treated as separate research areas.

Furthermore, farming systems research not only provides insights on the kinds of questions that we need to ask, but also how to go about research in the context of smallholder agriculture. Indeed, methodological concerns have been central to the field since the very beginning as researchers sought for ways to do justice to biophysical and socio-economic heterogeneity, the complex decision-making processes that surround smallholders' technology uptake and use, and farmers' capacity to contribute to knowledge production and experimentation (Norman 2002). Participatory research methods in particular came to be seen as key for understanding linkages, interactions, and trade-offs between sub-systems (e.g., cropping and livestock systems), priorities, and decision-making processes at the household level, and the many challenges faced by farmers in relation to new crops and practices

The basic logic is that farmer participation throughout the entire research process, including plant breeding, reduces the risk of targeting options that end up not being appealing or feasible for smallholders. It also enables understanding of how different options perform in real-world conditions according to criteria set by farmers rather than (only) by researchers (Murphy et al. 2005; Pretty 1997). Since these points were first raised in the 1960s, there have been numerous methodological development and refinements; see for example Dogliotti et al. (2014b). One example that could provide guidance for research on perennial crops is the "cyclical and 
Table 1 Key characteristics of smallholder farming systems and examples of research questions that follow from these characteristics

Characteristic of smallholder farming systems

Smallholder farming systems are complex, diverse, and locally adapted

\section{Stmallholdet farming systems are complex, diverse, and locally adapted t}

Smallholders' resource endowments are highly diverse, including at the local and intra-household level

Farming is often "semi-subsistence" and forms part of broader livelihood strategies, wherein risk is an important decision-making variable

Gender relations and roles influence many aspects of smallholder farming systems

Smallholders' strategies and decisions are influenced by political, economic, institutional factors and processes at scales beyond the local
Examples of questions for future research

How do perennial grain crops fit into existing farming systems (including mixed crop-livestock systems) in a particular locale? What types of systems, centered on perennial grains, have the most potential to constitute sustainable farming systems?

How is adoption of perennial grain crops shaped by different resource constraints at individual and household level (e.g., land, labor, capital)? Under what conditions are highly resource-constrained farmers likely to benefit?

Who is likely to adopt and benefit from new perennial grain cropssubsistence farmers, commercial farmers, or farmers across the spectrum? What types of risk are reduced/exacerbated by introduction of perennial grain crops in a given context?

How do gender relations and roles affect views on, and impacts of, perennial grain crops? Are these relations and roles in turn influenced by the uptake of perennial grain crops?

In what ways do existing political, economic, and institutional arrangements inhibit the development and uptake or perennial crops in a given context? What types of policy and institutional changes could enable the same?

adaptive approach" for re-designing farming systems proposed by Falconnier et al. (2017). This involves three stages, namely, co-design of a set of options, on-farm testing and appraisal, and finally a participatory ex ante analysis (Fig. 5). The importance of early farmer involvement is illustrated by Snapp et al. (2018), who remind us that in some parts of Africa, farmers already grow perennial and/or perennial-like crops like pigeon peas and ratooned sorghum. A participatory approach can help researchers to avoid the (thus far common) mistake of overlooking these practices and their logic, but equally be attentive to the many reasons why they may not exist in a given locality.

At the same time, it is necessary to acknowledge that the "participatory turn" in agricultural development research (and development research more broadly) has been subject to important criticisms. Numerous situations are documented where insufficient attention was given to local power dynamics, where pre-determined agendas were imposed on participants, or where "stakeholders" were included for purely instrumental reasons (see for example Cornwall 2008; Cooke and Kothari 2001; Beazley and Ennew 2006). Participatory research is furthermore an inherently challenging process in which farmers' diverse interests, expectations, and constraints, as well as social and interpersonal relations in the research locale, must be wellunderstood and carefully considered (Hauser et al. 2016). Navigating these complexities provides significant challenges for individual researchers and research teams, and tends to be resource and time intensive. On the flipside, there is much to be gained from "proper" participatory research into perennial grains. Close interaction with farmers could help build trust and might be an important first step in overcoming some of the above-mentioned obstacles to adoption.

\section{Conclusions}

In this article, motivated by the significant potential that perennial grains have in regard to sustainable agricultural development in many agroecosystems, we have developed a foundation for research on perennial grains in African smallholder context based on farming systems research. Although this is a large body of literature, containing many more important insights in relation to specific crops,

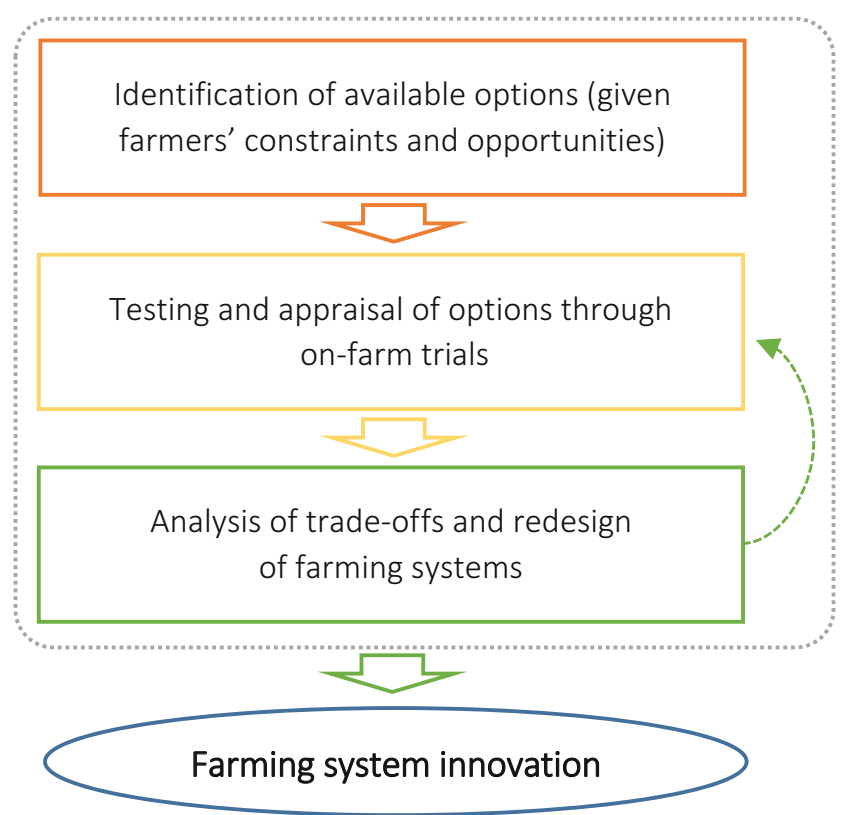

Fig. 5 Co-learning cycles for farming system innovation, where dialog with and active participation of farmers is central to all three steps. In reality, the cyclical process may involve several repetitions of the second and third steps (schematic adapted from Falconnier et al. 2017) 
cropping systems, practices, and localities than can be covered here, our synthesis highlights four pivotal considerations. These are (1) diversity, complexity, and local adaptation; (2) the many and varying resource-constraints that shape farmers' decision making; (3) the embeddedness of agricultural production in broader livelihood strategies; and (4) the centrality of social differentiation regarding resource use, access, and control, including gender relations.

Even though the primary value of the farming systems perspective lies in its commitment to a holistic approach, we argue that the emerging research agenda around perennial grains in African agricultural development must be even broader. We have argued that plant breeding and farming systems research on perennial grains should be complemented by critically and historically informed inquiry into political economic as well as cultural-ideological drivers of agricultural knowledge production and development efforts in different parts of Africa. We add this as a fifth pivotal consideration, which invites perspectives from outside the traditional research community around farming systems.

These insights all have methodological implications, and we particularly highlight the need for interdisciplinary collaboration and participatory approaches already in early stages of crop development. As such, we concur with the conclusion of Nakasagga et al. (2018) that on-farm evaluation and selection should be included as part of research on perennial grains from the beginning, even if some activities by necessity must occur within the realm of the research station.

Taken together, our review suggests that closer attention to farming system insights, political economic dynamics, and methodological considerations constitute important/ necessary steps towards accomplishing the transformative agricultural vision that perennial grain researchers are invested in.

Funding information Open access funding provided by Lund University. This study was funded by the Swedish Research Council, grant number 2016-06300.

\section{Compliance with ethical standards}

Conflict of interest The authors declare that they have no conflict of interest.

Open Access This article is licensed under a Creative Commons Attribution 4.0 International License, which permits use, sharing, adaptation, distribution and reproduction in any medium or format, as long as you give appropriate credit to the original author(s) and the source, provide a link to the Creative Commons licence, and indicate if changes were made. The images or other third party material in this article are included in the article's Creative Commons licence, unless indicated otherwise in a credit line to the material. If material is not included in the article's Creative Commons licence and your intended use is not permitted by statutory regulation or exceeds the permitted use, you will need to obtain permission directly from the copyright holder. To view a copy of this licence, visit http://creativecommons.org/licenses/by/4.0/.

\section{References}

Adebiyi J, Olabisi LS, Snapp S (2016) Understanding perennial wheat adoption as a transformative technology: evidence from the literature and farmers. Renew Agric Food Syst 31(2):101-110

Andersson E (2014) Fertile grounds? Collective strategies and the political ecology of soil management in Uganda. Dissertation, Lund University

Andersson E, Brogaard S, Olsson L (2011) The political ecology of land degradation. Annu Rev Environ Resour 36:295-319

Asante BO, Villano RA, Patrick IW, Battese GE (2018) Determinants of farm diversification in integrated crop-livestock farming systems in Ghana. Renew Agric Food Syst 33(2):131-149. https://doi.org/10. 1017/S1742170516000545

Beazley H, Ennew J (2006) Participatory methods and approaches: tackling the two tyrannies. Doing development research, pp 189-199

Bell LW, Byrne F, Ewing MA, Wade LJ (2008) A preliminary wholefarm economic analysis of perennial wheat in an Australian dryland farming system. Agric Syst 96(1-3):166-174. https://doi.org/10. 1016/j.agsy.2007.07.007

Bernstein H (2005) Rural land and land conflicts in Sub-Saharan Africa. In: Moyo S, Yeros P (eds) Reclaiming the land: the resurgence of rural movements in Africa. Asia and Latin America. Zed Books, London, pp 67-101

Brouwer R, Jansen K (1989) Critical introductory notes on farming systems research in developing third world agriculture. Systems Practice 2:379-395

Chambers R, Jiggins J (1987) Agricultural research for resource-poor farmers part I: transfer-of-technology and farming systems research. Agric Adm Ext 27(1):35-52

Chambers R, Pacey A, Thrupp LA (1994) Farmer first: farmer innovation and agricultural research. Intermediate Technology Publications, London

Christiaensen L (2017) Agriculture in Africa - telling myths from facts: a synthesis. Food Policy 67:1-11. https://doi.org/10.1016/j.foodpol. 2017.02.002

Collier P (2002) The future of perennial crops. Afr Dev Rev Revue Africaine De Developpement 14(2):237-250. https://doi.org/10. 1111/1467-8268.00053

Collinson M (2000) Introduction. In: Collinson M (ed) A history of farming systems research. CABI Publishing and FAO, Wallingford, pp 1-4

Collinson M, Lightfoot C (2000) The future of farming systems research. In: Collinson M (ed) A history of farming systems research. CABI Publishing and FAO, Wallingford, pp 391-419

Cooke B, Kothari U (2001) Participation: the new tyranny? Zed books, London

Cornwall A (2008) Unpacking 'participation': models, meanings and practices. Community Development Journal 43(3):269-283

Cox S (2014) Introduction: perennial crops for food security. In: Batello C, Wade L, Cox S, Pogna N, Bozzini A, Choptiany J (eds) Perennial Crops for Food Security. Proceedings of the FAO Expert Workshop, Rome

Cox TS, Glover JD, Van Tassel DL, Cox CM, DeHaan LR (2006) Prospects for developing perennial grain crops. BioScience 56(8): 649-659

Cox S, Nabukalu P, Paterson AH, Kong WQ, Nakasagga S (2018) Development of perennial grain sorghum. Sustainability 10(1). https://doi.org/10.3390/su10010172

Crews TE, Rumsey BE (2017) What agriculture can learn from native ecosystems in building soil organic matter: a review. Sustainability 9(4):915. https://doi.org/10.3390/su9040578

Crews TE, Blesh J, Culman SW, Hayes RC, Jensen ES, Mack MC, Peoples MB, Schipanski ME (2016) Going where no grains have gone before: from early to mid-succession. Agric Ecosyst Environ 223:223-238. https://doi.org/10.1016/j.agee.2016.03.012 
Crews TE, Carton W, Olsson L (2018) Is the future of agriculture perennial? Imperatives and opportunities to reinvent agriculture by shifting from annual monocultures to perennial polycultures. Global Sustainability 1:1-18

de Oliveira G, Brunsell NA, Sutherlin CE, Crews TE, DeHaan LR (2018) Energy, water and carbon exchange over a perennial Kernza wheatgrass crop. Agric For Meteorol 249:120-137. https://doi.org/10. 1016/j.agrformet.2017.11.022

Deininger K, Savastano S, Xia F (2017) Smallholders' land access in Sub-Saharan Africa: a new landscape? Food Policy 67:78-92. https://doi.org/10.1016/j.foodpol.2016.09.012

Devendra C (2001) Small ruminants: imperatives for productivity enhancement improved livelihoods and rural growth - a review. Asian Australas J Anim Sci 14(10):1483-1496. https://doi.org/10. 5713/ajas.2001.1483

Dogliotti S, García MC, Peluffo S, Dieste JP, Pedemonte AJ, Bacigalupe GF, Scarlato M, Alliaume F, Alvarez J, Chiappe M, Rossing WAH (2014a) Co-innovation of family farm systems: a systems approach to sustainable agriculture. Agric Syst 126:76-86. https://doi.org/10. 1016/j.agsy.2013.02.009

Dogliotti S, Rodríguez D, López-Ridaura S, Tittonell P, Rossing WAH (2014b) Designing sustainable agricultural production systems for a changing world: methods and applications. Agric Syst 126:1-2. https://doi.org/10.1016/j.agsy.2014.02.003

Doss C, Kovarik C, Peterman A, Quisumbing A, van den Bold MJAE (2015) Gender inequalities in ownership and control of land in Africa: myth and reality 46 (3):403-434

Falconnier GN, Descheemaeker K, Van Mourik TA, Adam M, Sogoba B, Giller KE (2017) Co-learning cycles to support the design of innovative farm systems in southern Mali. Eur J Agron 89:61-74. https:// doi.org/10.1016/j.eja.2017.06.008

Finlayson J, Bathgate A, Nordblom T, Theiveyanathan T, Farquharson B, Crosbie R, Mitchell D, Hoque Z (2010) Balancing land use to manage river volume and salinity: economic and hydrological consequences for the Little River catchment in Central West, New South Wales, Australia. Agric Syst 103(3):161-170. https://doi.org/10. 1016/j.agsy.2009.12.003

Gezon LL, Paulson S (2004) Place, power, difference: multiscale research at the dawn of the twenty-first century. In: Paulson S, Gezon LL (eds) Political ecology across spaces, scales and social groups. Rutgers University Press, New Brunswick, pp 1-16

Gilbert EH, Norman DW, Winch FE (1980) Farming systems research: a critical appraisal. MSU Rural Development Papers. Department of Agricultural Economics, Michigan State University

Gilbert CL, Christiaensen L, Kaminski J (2017) Food price seasonality in Africa: measurement and extent. Food Policy 67:119-132

Giller KE, Corbeels M, Nyamangara J, Triomphe B, Affholder F, Scopel E, Tittonell P (2011) A research agenda to explore the role of conservation agriculture in African smallholder farming systems. Field Crop Res 124(3):468-472

Glenna LL, Jussaume RA, Dawson JC (2011) How farmers matter in shaping agricultural technologies: social and structural characteristics of wheat growers and wheat varieties. Agric Hum Values 28(2): 213-224. https://doi.org/10.1007/s10460-010-9275-9

Glover JD, Culman SW, DuPont ST, Broussard W, Young L, Mangan ME, Mai JG, Crews TE, DeHaan LR, Buckley DH, Ferris H, Turner RE, Reynolds HL, Wyse DL (2010) Harvested perennial grasslands provide ecological benchmarks for agricultural sustainability. Agric Ecosyst Environ 137(1):3-12. https://doi.org/10.1016/j.agee.2009.11.001

Glover JD, Reganold JP, Cox CM (2012) Agriculture: plant perennials to save Africa's soils. Nature 489(4716):359-361

Grabowski P, Olabisi LS, Adebiyi J, Waldman K, Richardson R, Rusinamhodzi L, Snapp S (2019) Assessing adoption potential in a risky environment: the case of perennial pigeon pea. Agric Syst 171:89-99
Harvey CA, Rakotobe ZL, Rao NS, Dave R, Razafimahatratra H, Rabarijohn RH, Rajaofara H, MacKinnon JL (2014) Extreme vulnerability of smallholder farmers to agricultural risks and climate change in Madagascar. Philos Trans R Soc Lond Ser B Biol Sci 369(1639):20130089. https://doi.org/10.1098/rstb.2013.0089

Hauser M, Lindtner M, Prehsler S, Probst L (2016) Farmer participatory research: why extension workers should understand and facilitate farmers' role transitions. J Rural Stud 47:52-61. https://doi.org/10. 1016/j.jrurstud.2016.07.007

Henao J, Baanante C (2006) Agricultural production and soil nutrient mining in Africa: implications for resource conservation and policy development. International Center for Soil Fertility and Agricultural Development, Muscle Shoals

Holden ST, Otsuka K (2014) The roles of land tenure reforms and land markets in the context of population growth and land use intensification in Africa. Food Policy 48:88-97. https://doi.org/10.1016/j. foodpol.2014.03.005

Huang GF, Qin SW, Zhang SL, Cai XL, Wu SK, Dao JR, Zhang J, Huang LY, Harnpichitvitaya D, Wade LJ, Hu FY (2018) Performance, economics and potential impact of perennial rice PR23 relative to annual rice cultivars at multiple locations in Yunnan Province of China. Sustainability 10(4):1086. https://doi.org/10.3390/su10041086

Jackson W (2002) Natural systems agriculture: a truly radical alternative. Agric Ecosyst Environ 88:111-117

Jayne TS, Chamberlin J, Headey DD (2014) Land pressures, the evolution of farming systems, and development strategies in Africa: a synthesis. Food Policy 48:1-17. https://doi.org/10.1016/j.foodpol.2014.05.014

Jerneck A, Olsson L (2013) More than trees! Understanding the agroforestry adoption gap in subsistence agriculture: insights from narrative walks in Kenya. J Rural Stud 32:114-125

John AA, Jones CA, Ewing SA, Sigler WA, Bekkerman A, Miller PR (2017) Fallow replacement and alternative nitrogen management for reducing nitrate leaching in a semiarid region. Nutr Cycl Agroecosyst 108(3): 279-296. https://doi.org/10.1007/s10705-017-9855-9

Jordan NR, Dorn K, Runck B, Ewing P, Williams A, Anderson KA, Felice L, Haralson K, Goplen J, Altendorf K, Fernandez A, Phippen W, Sedbrook J, Marks M, Wolf K, Wyse D, Johnson G (2016) Sustainable commercialization of new crops for the agricultural bioeconomy. Elementa 4:1-10. https://doi.org/10.12952/ journal.elementa.000081

Kane DA, Roge P, Snapp SS (2016) A systematic review of perennial staple crops literature using topic modeling and bibliometric analysis. PLoS One 11(5). https://doi.org/10.1371/journal.pone.0155788

Kell DB (2012) Large-scale sequestration of atmospheric carbon via plant roots in natural and agricultural ecosystems: why and how. Philos Trans R SocB Biol Sci 367(1595):1589-1597. https://doi.org/10. 1098/rstb.2011.0244

Kloppenburg JR (2005) First the seed: the political economy of plant biotechnology. University of Wisconsin Press, Madison

Kuivanen KS, Alvarez S, Michalscheck M, Adjei-Nsiah S, Descheemaeker K, Mellon-Bedi S, Groot JCJ (2016) Characterising the diversity of smallholder farming systems and their constraints and opportunities for innovation: a case study from the Northern Region, Ghana. Wagening J Life Sci 78:153-166. https://doi.org/10.1016/j.njas.2016.04.003

Larkin PJ, Newell MT, Hayes RC, Aktar J, Norton MR, Moroni SJ, Wade LJ (2014) Progress in developing perennial wheats for grain and grazing. Crop Pasture Sci 65(11):1147-1164. https://doi.org/10. 1071/cp13330

Leonardo WJ, van de Ven GW, Udo H, Kanellopoulos A, Sitoe A, Giller KE (2015) Labour not land constrains agricultural production and food self-sufficiency in maize-based smallholder farming systems in Mozambique. Food Secur 7(4):857-874

Li TM (2007) Practices of assemblage and community forest management. Econ Soc 36(2):263-293 
Marquardt K, Vico G, Glynn C, Weih M, Eksvard K, Dalin P, Bjorkman C (2016) Farmer perspectives on introducing perennial cereal in Swedish farming systems: a sustainability analysis of plant traits, farm management, and ecological implications. Agroecol Sustain Food Syst 40(5): 432-450. https://doi.org/10.1080/21683565.2016.1141146

Martens JRT, Entz MH, Wonneck MD (2015) Review: redesigning Canadian prairie cropping systems for profitability, sustainability, and resilience. Can J Plant Sci 95(6):1049-1072. https://doi.org/ 10.4141/cjps-2014-173

Masters WA, Djurfeldt AA, De Haan C, Hazell P, Jayne T, Jirström M, Reardon T (2013) Urbanization and farm size in Asia and Africa: implications for food security and agricultural research. Glob Food Secur 2(3):156-165. https://doi.org/10.1016/j.gfs.2013.07.002

Morton JF (2007) The impact of climate change on smallholder and subsistence agriculture. Proc Natl Acad Sci 104(50):19680-19685

Murphy K, Lammer D, Lyon S, Carter B, Jones SS (2005) Breeding for organic and low-input farming systems: an evolutionaryparticipatory breeding method for inbred cereal grains. Renewable Agriculture and Food Systems 20(1):48-55

Nakasagga S, Biruma M, Tusiime G, Nabukalu P, Cox S (2018) Rhizome development in Sorghum bicolor $\times$ sorghum halepense families in the tropical ecosystem of Uganda. Afr J Agric Res 13(4):151-166

Newell MT, Hayes RC (2017) An initial investigation of forage production and feed quality of perennial wheat derivatives. Crop \& Pasture Science 68(12):1141-1148. https://doi.org/10.1071/cp16405

Norman D (2002) The farming systems approach: a historical perspective. In: The 17th Symposium of the International Farming Systems Association, Lake Buena Vista, Florida, USA, November 17th-20th, 2002

Ojiem JO, de Ridder N, Vanlauwe B, Giller KE (2006) Socio-ecological niche: a conceptual framework for integration of legumes in smallholder farming systems AU - Ojiem. J O Int J Agric Sustain 4(1):79 93. https://doi.org/10.1080/14735903.2006.9686011

Peter BG, Mungai LM, Messina JP, Snapp SS (2017) Nature-based agricultural solutions: scaling perennial grains across Africa. Environ Res 159:283-290. https://doi.org/10.1016/j.envres.2017.08.011

Pimentel D, Cerasale D, Stanley RC, Perlman R, Newman EM, Brent LC, Mullan A, Chang DT-I (2012) Annual vs. perennial grain production. Agric Ecosyst Environ 161:1-9. https://doi.org/10.1016/j.agee. 2012.05.025

Pretty JN (1997) The sustainable intensification of agriculture. Nat Res Forum 21(4):247-256

Reganold JP (2013) Perennial grain systems: a sustainable response to future food security challenges. In: Batello C, Wade LJ, Cox S, Pogna N, Bozzini A, Choptiany J (eds) Perennial crops for food security. Proceedings of the FAO expert workshop, Rome

Robbins P (2011) Political ecology: a critical introduction. Wiley, Chichester

Rocheleau D, Thomas-Slayter B, Wangari E (2013) Feminist political ecology: global issues and local experience. Routledge, London

Rogé P, Snapp S, Kakwera MN, Mungai L, Jambo I, Peter B (2016) Ratooning and perennial staple crops in Malawi. A review. Agron Sustain Dev 36(3):50

Rogé P, Diarisso T, Diallo F, Boire Y, Goita D, Peter B, Macalou M, Weltzien E, Snapp S (2017) Perennial grain crops in the West Soudanian Savanna of Mali: perspectives from agroecology and gendered spaces. Int J Agric Sustain 15(5):555-574. https://doi. org/10.1080/14735903.2017.1372850

Ryan MR, Crews TE, Culman SW, Dehaan LR, Hayes RC, Jungers JM, Bakker MG (2018) Managing for multifunctionality in perennial grain crops. BioScience 68(4):294-304. https://doi.org/10.1093/ biosci/biy014

Saunders B, Sim J, Kingstone T, Baker S, Waterfield J, Bartlam B, Burroughs H, Jinks C (2018) Saturation in qualitative research: exploring its conceptualization and operationalization. Qual Quant 52(4):1893-1907. https://doi.org/10.1007/s11135-017-0574-8

Schimmelpfennig DE, Pray CE, Brennan MF (2004) The impact of seed industry concentration on innovation: a study of US biotech market leaders. Agric Econ 30(2):157-167. https://doi.org/10.1016/j. agecon.2002.11.001

Scoones I (2009) Livelihoods perspectives and rural development. J Peasant Stud 36(1):171-196

Sewpaul VJA (2008) Transforming gendered relationships: rural women in Africa. Agenda 22(78):43-54

Sibanda T, Dobson HM, Cooper JF, Manyangarirwa W, Chiimba W (2000) Pest management challenges for smallholder vegetable farmers in Zimbabwe. Crop Prot 19(8):807-815. https://doi.org/10. 1016/S0261-2194(00)00108-3

Snapp S, Rogé P, Okori P, Chikowo R, Peter B, Messina J (2018) Perennial grains for Africa: possibility or pipedream? Exp Agric: 1-22. https://doi.org/10.1017/S0014479718000066

Sumberg J, Thompson J (2012) Contested agronomy: agricultural research in a changing world. Routledge, Abingdon

Swinnen JF (2010) The political economy of agricultural and food policies: recent contributions, new insights, and areas for further research. Appl Econ Perspect Policy 32(1):33-58

Tittonell P, Muriuki A, Shepherd KD, Mugendi D, Kaizzi K, Okeyo J, Verchot L, Coe R, Vanlauwe B (2010) The diversity of rural livelihoods and their influence on soil fertility in agricultural systems of East Africaa typology of smallholder farms. Agric Syst 103(2):83-97

Umar BB, Aune JB, Johnsen FH, Lungu O (2011) Options for improving smallholder conservation agriculture in Zambia. J Agric Sci 3(3):50

Unruh JD (2008) Carbon sequestration in Africa: the land tenure problem. J Gec 18(4):700-707

Vanlauwe B, Coyne D, Gockowski J, Hauser S, Huising J, Masso C, Nziguheba G, Schut M, Van Asten P (2014) Sustainable intensification and the African smallholder farmer. Curr Opin Environ Sustain 8:15-22

Verma R (2001) Gender, land and livelihoods in East Africa: through farmers' eyes. IDRC, Ottawa

Waldman KB, Richardson RB (2018) Confronting tradeoffs between agricultural ecosystem services and adaptation to climate change in Mali. Ecol Econ 150:184-193. https://doi.org/10.1016/j. ecolecon.2018.04.003

Waldman KB, Ortega DL, Richardson RB, Snapp SS (2017) Estimating demand for perennial pigeon pea in Malawi using choice experiments. Ecol Econ 131:222-230. https://doi.org/10.1016/j.ecolecon. 2016.09.006

Whitfield S, Dixon JL, Mulenga BP, Ngoma H (2015) Conceptualising farming systems for agricultural development research: cases from Eastern and Southern Africa. Agric Syst 133:54-62. https://doi.org/ 10.1016/j.agsy.2014.09.005

World Bank (2009) Gender in agriculture sourcebook. World Bank, Washington, D.C.

Zhang S, Wang W, Zhang J, Ting Z, Huang W, Xu P, Tao D, Fu B, Hu F (2014) The progression of perennial rice breeding and genetics. In: Batello C, Wade LJ, Cox S, Pogna N, Bozzini A, Choptiany J (eds) Perennial crops for food security. Proceedings of the FAO expert workshop, Rome

Zhang SL, Hu J, Yang CD, Liu HT, Yang F, Zhou JH, Samson BK, Boualaphanh C, Huang LY, Huang GF, Zhang J, Huang WQ, Tao DY, Harnpichitvitaya D, Wade LJ, Hu FY (2017) Genotype by environment interactions for grain yield of perennial rice derivatives (Oryza sativa L./Oryza longistaminata) in southern China and Laos. Field Crop Res 207:62-70. https://doi.org/10.1016/j.fcr.2017.03.007

Publisher's note Springer Nature remains neutral with regard to jurisdictional claims in published maps and institutional affiliations. 